\title{
Modeling phytoplankton production: problems with the Eppley curve and an empirical alternative
}

\author{
Mark J. Brush ${ }^{1, *}$, John W. Brawley ${ }^{2}$, Scott W. Nixon ${ }^{1}$, James N. Kremer ${ }^{3}$ \\ ${ }^{1}$ Graduate School of Oceanography, University of Rhode Island, Narragansett, Rhode Island 02882-1197, USA \\ ${ }^{2}$ Tetra Tech EM Inc., 440 Commercial St., Boston, Massachusetts 02109, USA \\ ${ }^{3}$ Department of Marine Sciences, University of Connecticut at Avery Point, Groton, Connecticut 06340, USA
}

\begin{abstract}
Papers reporting the results of dynamic simulation models of aquatic ecosystems tend to show predicted concentrations of the state variables. The phytoplankton compartment is typically represented as predicted biomass, expressed as the concentration of chlorophyll $a$, particulate carbon, or particulate nitrogen. While computed values of phytoplankton biomass generally agree with observations, many of these same models significantly underestimate primary production. Existing simulation models often base the calculation of primary production on the Eppley curve, which sets the maximum daily phytoplankton growth rate as a function of temperature. Despite the apparent wide applicability of the Eppley curve, an increasing number of culture and field studies have measured growth rates in excess of those predicted by the curve, which may explain why existing models often underestimate primary production. An alternate empirical formulation which predicts daily phytoplankton production from biomass, photic depth, and incident irradiance has been shown to apply in a variety of nutrient-rich estuarine systems. Despite the large number of systems in which these empirical models have been developed, they predict remarkably similar rates of daily and annual production. Furthermore, these empirical models predict rates of production in excess of those predicted by the Eppley curve. The empirical formulation therefore presents an alternative to the Eppley curve in dynamic ecosystem models, and may result in more accurate predictions of primary production by these models.
\end{abstract}

KEY WORDS: Phytoplankton $\cdot$ Primary production $\cdot$ Ecosystem model $\cdot$ Empirical model

\section{INTRODUCTION}

Dynamic simulation models have become increasingly important as tools for the study and management of coastal marine ecosystems. Such models have been developed for a variety of estuarine systems, including Narragansett Bay (Kremer \& Nixon 1978), Chesapeake Bay (Cerco \& Cole 1994), the Delaware inland bays (Cerco et al. 1994), the North Sea (Fransz et al. 1991, Baretta et al. 1995), the Baltic Sea (Stigebrandt \& Wulff 1987, Savchuk \& Wulff 1993, 1996), and the Lagoon of Venice (Bergamasco et al. 1998).

*E-mail: brush@vims.edu
Output from simulation models is generally reported in terms of standing stocks rather than rate processes, e.g. as phytoplankton biomass (chlorophyll $a$, particulate carbon, or particulate nitrogen) rather than daily or annual primary production. If one is to use models to study ecosystem functions such as nutrient cycling, carbon fluxes, and oxygen dynamics, however, it is of critical importance to accurately simulate rate processes as well as state variables. In the few cases where modeled annual production is reported and compared to in situ measurements, existing models often underestimate the rate of primary production (Table 1). While this comparison may be somewhat complicated by year-to-year variations in the rate of annual production, models also often underestimate 
Table 1. Examples of models which underestimate annual primary production $\left(P_{\mathrm{r}} \mathrm{gC} \mathrm{m}^{-2} \mathrm{yr}^{-1}\right)$. All observed estimates are based on ${ }^{14} \mathrm{C}$ incubations

\begin{tabular}{lcc}
\hline Study area & Observed & Modeled \\
\hline Narragansett Bay $^{\mathrm{a}}$ & 310 & $60-155$ \\
Chesapeake Bay $^{\mathrm{b}}$ & 320 & 170 \\
Lake Glumsø, Denmark $^{\mathrm{c}}$ & $1050-1800$ & $850-1050$ \\
Baltic Sea $^{\mathrm{d}}$ & 135 & 80
\end{tabular}

${ }^{a}$ Observed $P_{\mathrm{yr}}$ is a bay-wide, area-weighted estimate based on C. A. Oviatt et al. (2002) for 1997-8; modeled $P_{\mathrm{yr}}$ is the range for the entire bay for $1972-3$ from Kremer \& Nixon (1978). Oviatt et al. report the first area-weighted estimate of $P_{\mathrm{yr}}$ for the entire bay, which is nearly identical to past estimates at single stations

b Observed $P_{\mathrm{yr}}$ data are from 1985-1996 or 1990-1993, depending on location; modeled $P_{\mathrm{yr}}$ is the average for the period 1985-1994 (see Nixon et al. 1999; model described by Cerco \& Cole 1994). Both estimates are averages of the values at the same 6 locations down the main axis of the bay

c Observed and modeled $P_{\mathrm{yr}}$ are for 1972-1975 (Jørgensen 1976). This author does not identify where measured values were taken, but the observations are directly compared with the model predictions in the paper, so we take them to apply to the same geographic location. Jørgensen suggests the value of $1800 \mathrm{~g} \mathrm{C} \mathrm{m}^{-2} \mathrm{yr}^{-1}$ may be an overestimate due to insufficient sampling of production over depth the first year of the study

${ }^{\mathrm{d}}$ Observed $P_{\mathrm{yr}}$ is an area-weighted estimate for the entire Baltic around 1980 (Elmgren 1984, 1989); modeled $P_{\mathrm{yr}}$ is also for the entire Baltic and corresponds to a model run forced by meteorological data randomly selected within the standard deviation of weekly 20 yr means (Savchuk \& Wulff 1993)

rates of daily production when compared to measurements on the same day (e.g. Cerco \& Cole 1994, HydroQual \& Normandeau Associates 1995).

On first examination of Table 1, one might wonder how models that produce reasonable predictions of phytoplankton biomass can simultaneously underestimate phytoplankton production. We believe this apparent paradox is due to a concurrent underestimation in the phytoplankton loss processes. Several such losses exist, including respiration, flushing, sinking, and grazing by various size fractions of zooplankton as well as benthic filter feeders. These losses are characterized by large spatial and temporal variability. Many are poorly constrained or need to be estimated a priori due to insufficient data (or a lack of data) in the literature (e.g. Broekhuizen et al. 1995, Ebenhöh et al. 1995). Often parameter values are set during calibration to achieve an acceptable fit between predicted and observed biomass (e.g. Cerco \& Cole 1994). In this case, if a model is underestimating production, the calibrated values for the loss terms would be set below their true values to obtain correct predictions of bio- mass. Further, some loss processes such as grazing are dependent on entirely separate state variables (e.g. zooplankton, benthic filter feeders) which are difficult to simulate accurately due to increased biological complexity (e.g. Kremer \& Nixon 1978). Finally, there are simply far more loss processes operating in any system than can be included in a model, so they are frequently aggregated into a small number of terms which loses considerable biological detail and accuracy (Rigler \& Peters 1995, Hofmann \& Lascara 1998).

Whatever the source of error in the loss terms, simultaneous underestimation of production and losses could nevertheless lead to correct estimates of biomass. While certain model applications might require accurate estimates of biomass alone, many models include additional components of the ecosystem such as dissolved nutrients and oxygen, to which the phytoplankton formulations are closely coupled. Since phytoplankton production occurs at the base of the food web and is directly related to carbon, nutrient, and oxygen cycling, it has great influence on the dynamics of these other system components. Thus, if one is concerned with predicting concentrations and processes in the system for components other than the phytoplankton, such as bottom-water oxygen concentrations under nutrient-reduction scenarios, it is critical to accurately predict phytoplankton production as well as biomass. When phytoplankton production is underestimated in such applications, accurate predictions of the concentrations of phytoplankton, nutrients, and oxygen are likely to be more the result of parameter adjustment during calibration than model dynamics (Bowie et al. 1985). This weakens the conclusions of such models as well as their utility in management applications.

The discrepancy between measured and modeled production warrants an examination of the way in which existing simulation models calculate phytoplankton production. It should be noted that the following discussion as well as the analyses and conclusions to come apply only to dynamic simulation models of aquatic ecosystems. Our work does not apply to models that compute production and growth from measured biomass and irradiance combined with a detailed integration of a photosynthesis-irradiance $(P-I)$ function over depth and time (e.g. Behrenfeld \& Falkowski 1997), or to bio-optical models which compute production as a function of various photophysiological parameters (e.g. Sosik 1996).

The general approach to modeling phytoplankton production in dynamic models begins with the calculation of the maximum attainable daily growth rate, $G_{\max }$ $\left(d^{-1}\right)$ (base e), from forced environmental variables, most commonly temperature (Bowie et al. 1985, Cullen et al. 1993). $G_{\max }$ describes the rate at which phyto- 
plankton will grow under optimal conditions; for example, under $24 \mathrm{~h}$ of continuous (and presumably optimum) irradiance and conditions of nutrient sufficiency.

This maximum growth rate is then reduced by factors that prevent the phytoplankton from realizing this hypothetical maximum rate. If $G_{\max }$ is set as a function of temperature, then these limiting factors include daylength (coded as photoperiod, $f$ ), sub-optimal light throughout the day and over the photic depth, and limiting nutrient concentrations:

$$
G=G_{\max } \cdot f \cdot \text { LTLIM } \cdot \text { NUTLIM }
$$

where $G$ is the realized daily growth rate $\left(\mathrm{d}^{-1}\right)$ (base e), $f$ is the fraction of the day during which there is light, and LTLIM and NUTLIM are dimensionless ratios from 0 to 1 which describe light and nutrient limitation of growth, respectively (e.g. Kremer \& Nixon 1978).

$G_{\max }$ is most frequently expressed as a function of temperature (Bowie et al. 1985, Cullen et al. 1993). In early models, this relationship was often described by a linear function (e.g. DiToro et al. 1971). More recently, the most commonly used temperature formulation was derived by Eppley (1972), who compiled a database of culture studies in which growth rates of approximately 130 species or clones of phytoplankton were measured at a variety of temperatures under $24 \mathrm{~h}$ of continuous illumination and conditions of nutrient sufficiency. When growth rates were plotted against temperature, Eppley found that the data fell below an envelope which was exponential in shape and could be described by the following equation expressed in base e:

$$
G_{\max }=0.59 \mathrm{e}^{0.0633 T}
$$

where $T=$ water temperature. This exponential function has come to be known as the 'Eppley curve' and is commonly taken to define the maximum attainable daily growth rate under non-limiting conditions of light and nutrients.

The Eppley curve or a similar temperature-based function has been used to set the maximum daily growth rate in a variety of estuarine, lacustrine, and open ocean models (Fig. 1). We reviewed 112 papers, reports, chapters, and other documents reporting the results of 60 different estuarine and nearshore dynamic simulation models produced between 1971 and 2000. Of these 60 models, 53 set $G_{\max }$ as a function of temperature, either with the Eppley curve, a similar temperature-dependent function, or by using the following variation on Eq. (1):

$$
G=G_{\max } \cdot \operatorname{TLIM} \cdot f \cdot \operatorname{LTLIM} \cdot \mathrm{NUTLIM}
$$

where the highest attainable value of $G_{\max }$ is specified as a fixed rate and the exponential relationship to temperature is expressed as a unitless ratio from 0 to 1

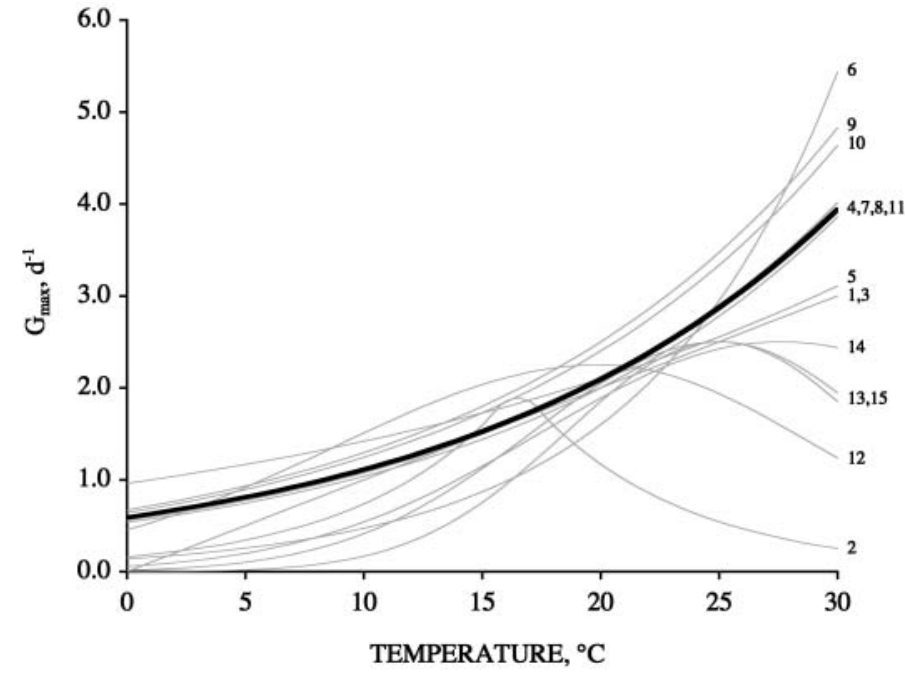

Fig. 1. Temperature-dependent functions for the maximum daily phytoplankton growth rate (base e) in a variety of dynamic simulation models. The bold line is the Eppley curve. Sources which use the Eppley curve directly include models of Lake Ontario (Thomann et al. 1975), Narragansett Bay (Kremer \& Nixon 1978), the Baltic Sea (Stigebrandt \& Wulff 1987), the outer southeastern US continental shelf (Hofmann \& Ambler 1988), the subarctic Pacific (Matear 1995), and nearshore regions of Chesapeake Bay (Madden \& Kemp 1996). Sources which use a variation of the Eppley Curve include models of the following systems and species groups: 1, Sacramento-San Joaquin Delta (DiToro et al. 1971); 2, Lake Glumsø (Jørgensen 1976); 3, Potomac River (DiToro et al. 1977); 4, Lake Huron and Saginaw Bay (DiToro \& Matystik 1980); 5, Lake Erie diatoms (DiToro \& Connolly 1980); 6 , other Lake Erie phytoplankton (DiToro \& Connolly 1980); 7, Potomac River (Thomann \& Fitzpatrick 1982); 8, Chesapeake Bay main stem (HydroQual 1987); 9, James, York, and Rappahannock Rivers (HydroQual 1987); 10, Patuxent River (HydroQual 1987); 11, the WASP (Water Quality Analysis Simulation Program) model (Ambrose et al. 1993); 12, Chesapeake Bay diatoms (Cerco \& Cole 1994); 13, Chesapeake Bay green algae (Cerco \& Cole 1994); 14, Chesapeake Bay cyanobacteria (Cerco \& Cole 1994); 15, Indian River Lagoon and Rehoboth Bay (Cerco et al. 1994)

(TLIM) analogous to LTLIM and NUTLIM. Though Eq. (3) is expressed slightly differently from Eq. (1), the 2 formulations produce the same result. The 7 models that did not set $G_{\max }$ as a function of temperature defined a maximum growth rate and reduced it to account for light and/or nutrient limitation.

A similar literature review demonstrated that lacustrine models typically use temperature-dependent $G_{\max }$ functions as well. The situation is different for models of the continental shelf and open ocean, however. While a good number of these models do use an Eppley-type relationship, many compute phytoplankton growth rate only as a function of light and nutrients (e.g. Evans \& Parslow 1985, Fasham et al. 1990). Exclusion of temperature in these models is justified due 


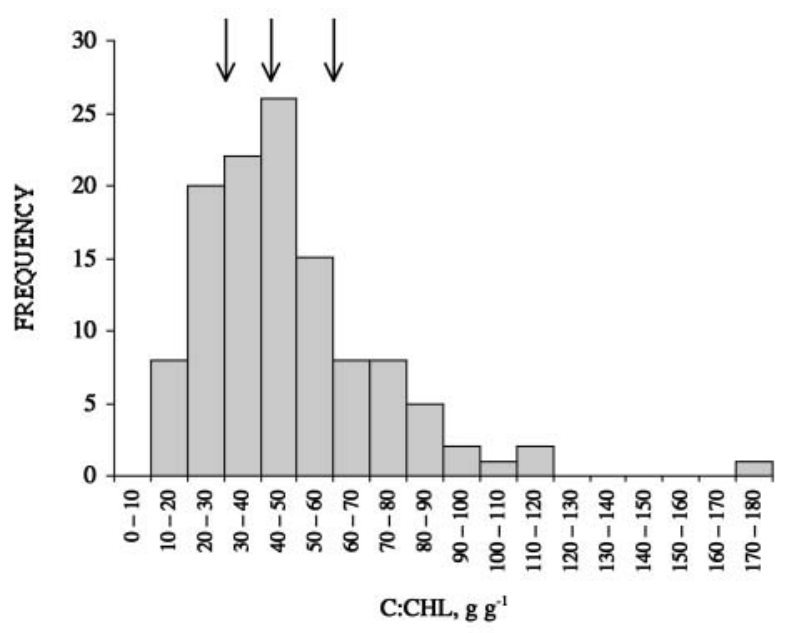

Fig. 2. Histogram of carbon-to-chlorophyll (C:chl) ratios measured in light-limited cultures compiled by Cloern et al. (1995). Arrows denote the first quartile $(\mathrm{C}: \mathrm{chl}=30)$, median $(\mathrm{C}: \mathrm{chl}=42)$, and third quartile $(\mathrm{C}: \mathrm{chl}=60)$

in part to the much smaller annual temperature range in open-ocean systems as compared to lakes and estuaries.

Additionally, many open-ocean models are steadystate models which are run over short time periods in which water temperatures do not change a large amount.

The discrepancy between measured and modeled rates of primary production, together with the importance of accurately predicting such rates, has led us to examine the traditional way in which phytoplankton growth and primary production are formulated in aquatic simulation models, and in particular the use of the Eppley curve. We have searched the literature for evidence of culture studies which violate the curve, and have compared growth rates measured in situ to those predicted by the Eppley curve from 2 estuaries (Narragansett Bay, RI, and Waquoit Bay, MA) and 2 mesocosm facilities at the University of Rhode Island (URI Marine Ecosystems Research Laboratory [MERL] and the URI Lagoon Mesocosm Facility). An empirical alternative to Eppley's curve is presented and examined for its potential application in estuarine simulation models.

\section{MATERIALS AND METHODS}

To compare growth rates predicted by the Eppley curve with those measured in situ, we compiled datasets consisting of temperature, chlorophyll, and daily production from Narragansett Bay, Waquoit Bay, MERL, and the Lagoon Mesocosm Facility. Growth rates were calculated according to:

$$
G=\frac{1}{\Delta t} \ln \left(\frac{C_{0}+\Delta C}{C_{0}}\right)
$$

where $\Delta t=1 \mathrm{~d}, C_{0}=$ initial phytoplankton biomass in carbon units, and $\Delta C=$ daily increase of phytoplankton biomass due to production (in carbon units). This equation is derived from the exponential growth equation and is commonly used to calculate growth rates from biomass or cell count data (Eppley 1972).

Chlorophyll data. The ideal dataset for this analysis would consist of phytoplankton biomass measured as carbon and phytoplankton production measured as ${ }^{14} \mathrm{C}$ uptake. However, data for phytoplankton carbon biomass is lacking due to the difficulty in separating the phytoplankton from other sources of carbon (e.g. zooplankton, detritus, microbes) when filtering water samples. As such, we have had to use measurements of chlorophyll a ( $\mathrm{chl} \mathrm{a)} \mathrm{concentrations} \mathrm{as} \mathrm{a} \mathrm{proxy} \mathrm{for}$ phytoplankton biomass, and convert to carbon units using the carbon-to-chlorophyll ratio (C:chl). Cloern et al. (1995) compiled C:chl ratios from a variety of culture studies and classified them according to whether the cultures were light-limited or nutrient-limited. Despite a wide range of values, the $\mathrm{C}$ :chl ratios compiled by Cloern et al. for light-limited conditions, which are the prevailing conditions in the estuaries we are simulating, show a distinct peak at a median value of 42 , with first and third quartiles of 30 and 60, respectively (Fig. 2). We have taken the first and third quartiles to define the range over which $\mathrm{C}$ :chl is most likely to vary, and have converted all chlorophyll data into carbon units using a C:chl of 30 and 60. Therefore, all calculations of measured growth rates and comparisons to the Eppley curve will be done at a C:chl of 30 and 60 .

Production data. Production was measured as the rate of ${ }^{14} \mathrm{C}$ uptake in MERL and Narragansett Bay and as the production of $\mathrm{O}_{2}$ in Waquoit Bay and the Lagoon Mesocosm Facility. Production in the MERL mesocosms was measured biweekly by Keller (1988a) from 1982 to 1983 during a nutrient-addition experiment in which tanks received inorganic nutrient additions from 0 to 32 times the estimated loading rate to Narragansett Bay. Bottles were suspended at 5 depths in the MERL tanks for $4 \mathrm{~h}$ around midday. The hyperbolic tangent equation of Platt \& Jassby (1976) was fit to the resulting photosynthesis-irradiance $(P-I)$ curves, producing estimates of the light-saturated hourly production rate. These hourly rates were multiplied by 24 to obtain light-saturated daily rates, which are directly comparable to the Eppley curve. Data from all tanks were pooled for this analysis.

Production in Narragansett Bay was measured from 1997 to 1998 by Oviatt et al. (2002). Water was collected approximately biweekly from 3 stations in Narragansett Bay and placed in bottles which were hung 
at 18 depths in the MERL mesocosms. Incubations lasted for $2 \mathrm{~h}$ around midday. $P$ - $I$ curves were fit and the light-saturated hourly production rates were converted to $24 \mathrm{~h}$ rates as described above. It should be noted that, while growth rates calculated from the ${ }^{14} \mathrm{C}$ data are directly comparable to the Eppley curve because they represent rates in $24 \mathrm{~h}$ of continuous illumination, any effects of nutrient limitation would have necessarily been incorporated into the measurements. In contrast, the Eppley curve predicts rates under conditions of nutrient sufficiency. As a result, this comparison of measured growth rates to the Eppley curve is conservative.

Incubations in Waquoit Bay were conducted by I. Valiela et al. (unpubl. data) in light and dark bottles for 3.5 to $10 \mathrm{~h}$ during morning and early afternoon from 1991 to 1993. Measurements were made at 1 to 2 depths in the Quashnet River, the Childs River, Sage Lot Pond, and the main bay every $2 \mathrm{wk}$ from March to November. Production in the light bottles was extrapolated to net daytime apparent production.

Net daytime apparent production in the Lagoon Mesocosm Facility was measured by Milliken (1991), Taylor et al. (1995), and S. Granger (unpubl. data) using the diel oxygen curve method of Odum \& Hoskin (1958) and the dawn-dusk-dawn oxygen method of Oviatt et al. (1986). Production was measured in clear metabolic chambers which enclosed the entire water column and isolated the water from the atmosphere and sediments. Data presented here were collected at various times during 1989, 1991, and 1997, and were pooled from all tanks across a range of inorganic nitrogen and phosphorus loading rates. The 1989 and 1991 experiments are described in Milliken (1991) and Taylor et al. (1995), respectively.

All oxygen data were converted to carbon units using a photosynthetic quotient of 1.2. Production rates based on oxygen represent net daytime ecosystem production rather than net daytime primary production, as they include losses of oxygen due to heterotrophic respiration. These losses lower the observed rate of production below that due to phytoplankton alone, which would be the appropriate comparison to the Eppley curve. As a result, the measured growth rates based on oxygen are underestimates of phytoplankton primary production, so this comparison of measured rates to the Eppley curve is quite conservative.

\section{RESULTS}

\section{Culture studies}

In his paper, Eppley (1972) notes that he omitted some data points which seemed unreasonably high from his analysis of growth rates as a function of temperature. From this initial indication of some apparent violations of the Eppley curve, we have found several culture studies published both before and after Eppley's paper in 1972 which report growth rates in excess of those predicted by the Eppley curve (Fig. 3).

We were able to find 59 growth rates measured in $24 \mathrm{~h}$ of continuous illumination which exceed the Eppley curve (Fig. 3a). Since they were measured in continuous light, these growth rates are directly comparable to Eppley's curve and suggest that the curve is simply too low. One can fit a new upper envelope to the data as a 'modified' Eppley curve using the same exponential rate of increase:

$$
G_{\max }=0.97 \mathrm{e}^{0.0633 T}
$$

We found an additional 62 growth rates which were measured under a daily light-dark cycle, but which exceed the Eppley curve when linearly extrapolated to a $24 \mathrm{~h}$ photoperiod, as is commonly done in ecosystem models (e.g. Kremer \& Nixon 1978) (Fig. 3b). However, a number of culture studies have shown a non-linear relationship between photoperiod and growth, in which growth rate increases relatively quickly, reaches $G_{\max }$ at $f<24 \mathrm{~h}$, and then remains constant up to $f=$ 24 h (e.g. Castenholz 1964, Paasche 1967, 1968, Sakshaug \& Andresen 1986). In these cases, linearly extrapolating growth rates measured under a lightdark cycle to $24 \mathrm{~h}$ rates would result in an overestimate of growth rate. We have therefore plotted both the original data (under the experimental light-dark cycles) as well as the $24 \mathrm{~h}$ extrapolated rates in Fig. 3b. All of the data shown exceed the Eppley curve in the latter case. The true growth rates lie somewhere between these 2 extremes, and several would still exceed the curve.

\section{Field measurements}

Several of the growth rates computed from ${ }^{14} \mathrm{C}$ productivity measurements in MERL and Narragansett Bay exceed the Eppley curve across the typical range of $\mathrm{C}$ :chl ratios (Fig. 4). A greater number of points exceed the curve at the lower C:chl ratio of 30. As for the culture data, the measured rates suggest that Eppley's exponential upper envelope is too low.

It is unclear why relatively few data points from the Narragansett Bay study violate the Eppley curve compared to the MERL experiment, although it is possible that nutrient limitation kept production rates low in the former study. As mentioned previously, the measured rates incorporate the effects of nutrient limitation, while the Eppley curve applies to conditions of nutrient sufficiency. In contrast, the MERL experiment spanned 
a 32-fold gradient in nutrient loading rate, so nutrients would have been much less limiting during the incubations from that experiment.
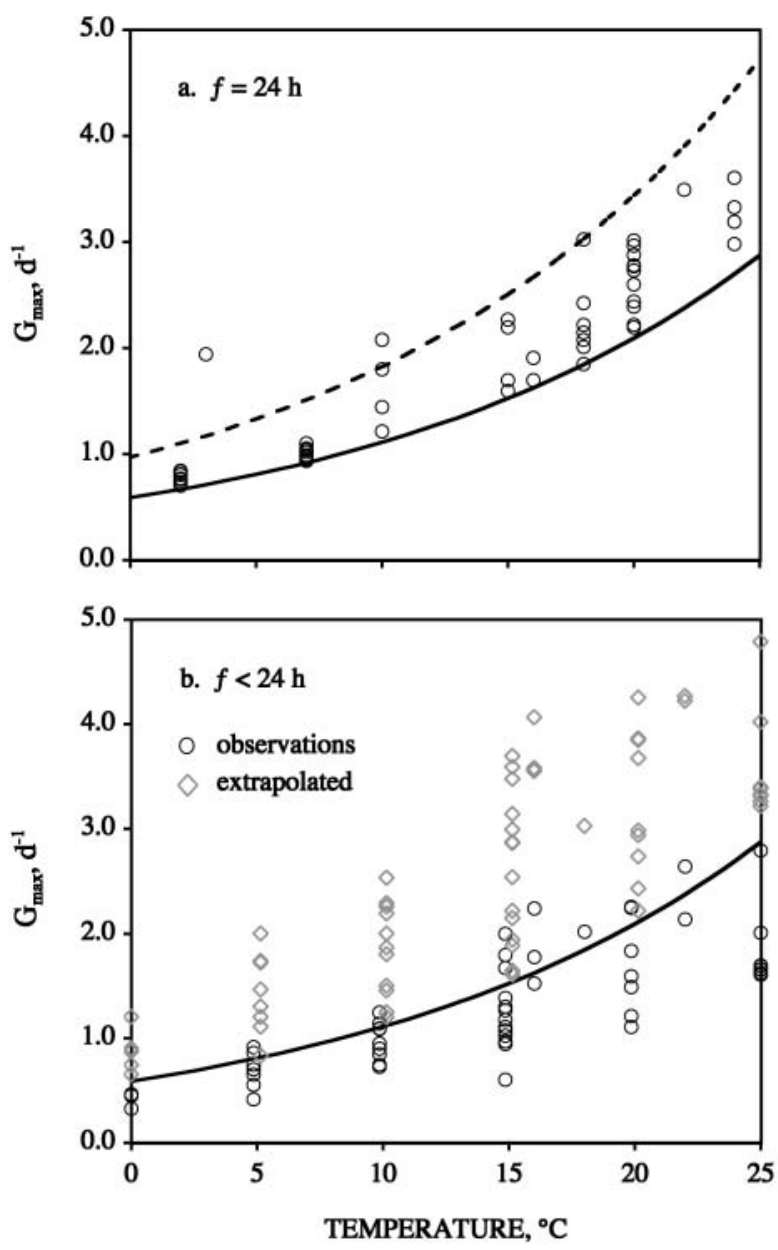

Fig. 3. (a) Instantaneous daily growth rates measured in culture which exceed the Eppley curve (solid line). Data $(\mathrm{n}=59)$ were converted from divisions $\mathrm{d}^{-1}$ (base 2) to $\mathrm{d}^{-1}$ (base e). Rates were measured under $24 \mathrm{~h}$ of continuous illumination and are thus measures of $G_{\max }$ and directly comparable to the Eppley curve. The broken line attempts to define the upper envelope of the data (Eq. 5). (b) As for (a), but rates were measured on a light-dark cycle with light periods ranging from 9 to $16 \mathrm{~h}$. All of these data $(\mathrm{n}=62)$ exceed the Eppley curve when linearly extrapolated to a $24 \mathrm{~h}$ light period $(f)$ (diamonds). The true $24 \mathrm{~h}$ growth rates $\left(G_{\max }\right)$ lie somewhere between these 2 extremes, suggesting that several would still exceed the Eppley curve. Data points have been slightly offset in the $x$ dimension at a given temperature so one can see all the points. Culture data were compiled from Braarud (1945), Curl \& McLeod (1961), Parsons et al. (1961), Guillard \& Ryther (1962), Smayda (1969), Davis et al. (1973), Paasche (1973), Durbin (1974), Thomas \& Dodson (1975), Throndsen (1976), Sakshaug \& Holm-Hansen (1977), Furnas (1978), Goldman \& McCarthy (1978), Yoder (1979), Brand \& Guillard (1981), Brand et al. (1981), Gallagher (1982), Krawiec (1982), Verity (1982), Sakshaug \& Andresen (1986), and Langdon $(1987,1988)$
Several of the growth rates based on $\mathrm{O}_{2}$ data from Waquoit Bay and the lagoon mesocosms also violate the Eppley curve (Fig. 5). While this violation is more significant at the lower C:chl ratio, it also occurs to a large degree at the higher ratio. These violations are even more significant than they appear, since the rates are derived from net ecosystem production rather than net phytoplankton production. The upper envelope of both datasets approximate straight lines, suggesting the lack of a relationship between $\mathrm{O}_{2}$-based growth rates and temperature.

The data in Fig. 5 were measured under natural conditions and represent production during the daylight hours, so they incorporate the effects of photoperiod as well as light and nutrient limitation. In contrast, the Eppley curve represents growth rates under conditions of continuous $(24 \mathrm{~h})$ illumination and nutrient sufficiency. It is striking that so many of the measured growth rates nevertheless exceed this theoretical maximum attainable $24 \mathrm{~h}$ growth rate.

If one considers that daylength is $12 \mathrm{~h}$ on average, the Eppley curve would need to be reduced by $50 \%$ for more direct comparison with the measured rates. We have therefore included curves in Fig. 5 which represent $50 \%$ of the Eppley curve. These lines still do not take into account the effects of sub-optimal light and nutrient limitation, so the comparison of measured and predicted rates is again conservative. Nevertheless, comparison of the measured rates to the reduced Eppley curve reveals an even larger discrepancy between measured and predicted rates.

\section{DISCUSSION}

Our results indicate that the Eppley curve underestimates growth rates from a variety of both culture and field studies. This underestimation may explain why many existing simulation models, in which the calculation of daily production is often rooted in the Eppley curve, underestimate primary production. One possible solution to this problem is simply to use a formulation similar to the Eppley curve which predicts higher growth rates for a given temperature. For example, one could use the new upper envelope proposed for the culture data in Fig. 3a (Eq. 5). This approach has been followed in several existing models, most of them more recent than those in Fig. 1 (Fig. 6). It is apparent from Fig. 6 that some models use formulations much higher than would be supported by measured data (e.g. Fig. 3a). While this approach is attractive as it continues to rely on first principles (i.e. the mechanistic relationship between temperature and $G_{\max }$ ), it is worth noting that the models of Savchuk \& Wulff (1993), Soetaert et al. (1994), and HydroQual \& Nor- 


\section{a. MERL NUTRIENT ADDITION EXPERIMENT}
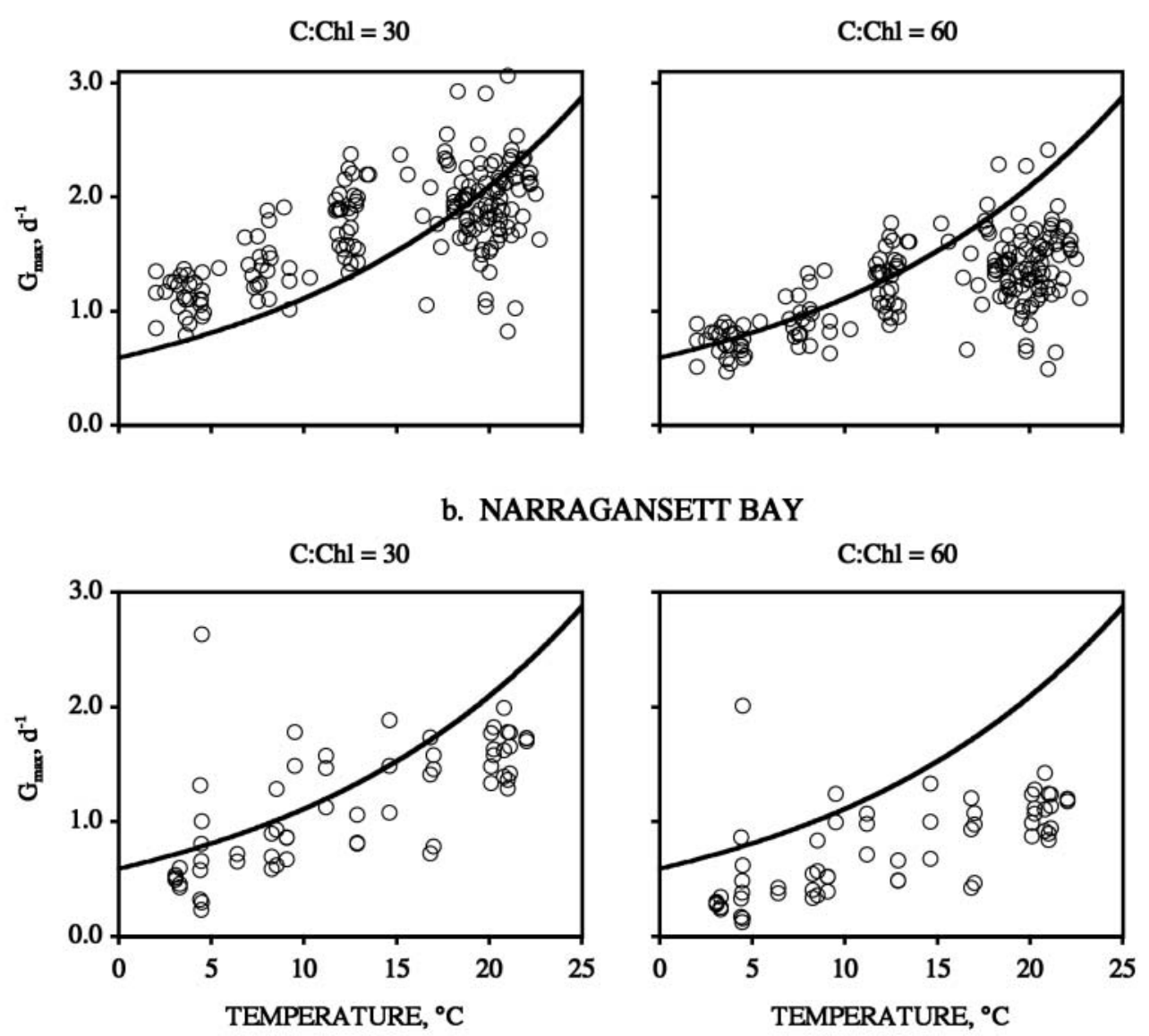

Fig. 4. Instantaneous daily growth rates (base e) calculated from chlorophyll a concentrations and ${ }^{14} \mathrm{C}$-based productivity measured (a) during the MERL nutrient addition experiment and (b) in Narragansett Bay, RI. See text for details of the measurements. Growth rates were calculated from empirically determined rates of light-saturated production $\left(P_{\max }\right)$ and therefore are estimates of $G_{\max }$. Solid line is the Eppley curve

mandeau Associates (1995) all use an elevated Eppley function but still underestimate production (see Table 1 and surrounding text). It is therefore worthwhile to search for another alternative.

A second solution may lie in the correction of the Eppley $G_{\max }$ for photoperiod. The maximum daily growth rate from the Eppley curve is generally reduced by the fraction of the day during which there is light, thereby accounting for photoperiod in a linear manner (e.g. Kremer \& Nixon 1978). However, as discussed above some culture studies have reported results in which the relationship between photoperiod and growth is in fact non-linear (e.g. Castenholz 1964, Paasche 1967, 1968, Sakshaug \& Andresen 1986). In these studies, most or all of the daily growth was completed after 15 to $19 \mathrm{~h}$, with little additional growth occurring beyond this up to $24 \mathrm{~h}$. If this is generally true, then a linear correction of rates predicted by the Eppley curve would result in an underestimate of the true growth rate. Accounting for this non-linearity in an Eppley-based model would thus result in higher predicted growth rates and therefore higher rates of production than would a linear correction.

In the face of uncertainties regarding just how high to set an elevated Eppley function and just how universal the non-linearity between photoperiod and growth rate is (and exactly what the relationship is), it may be desirable to seek an entirely different type of formulation. A third option would therefore be to turn to the rich literature based on computation of watercolumn production from measured biomass and irradiance coupled to a detailed integration of the $P$ - $I$ curve over depth and time (e.g. Platt 1986, Platt et al. 1990, Behrenfeld \& Falkowski 1997). It would be possible to insert modeled chl a during each time step into these equations along with forced irradiance.

However, these models still require the specification of the maximum photosynthetic rate, $P_{\max }$ (analogous 


\section{a. WAQUOIT BAY}
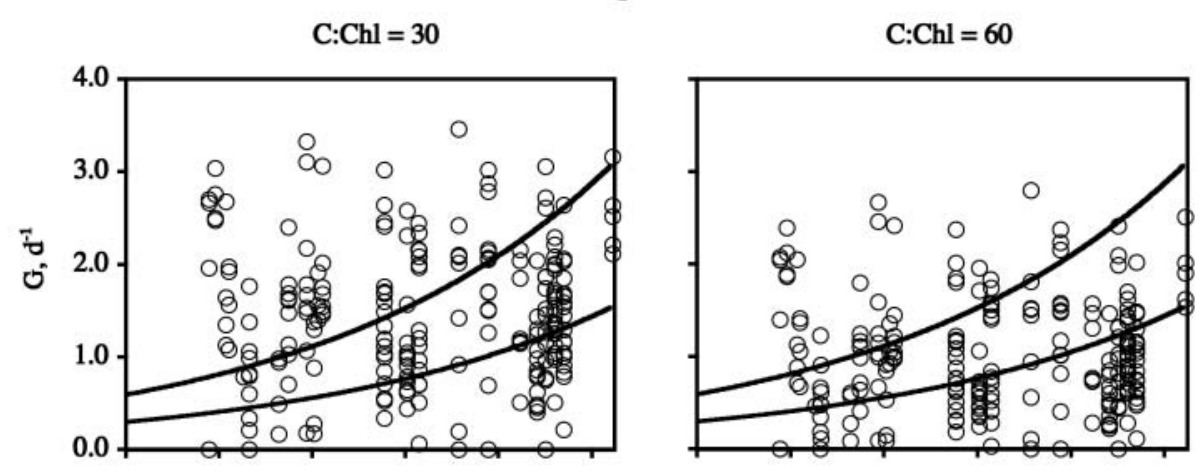

\section{b. LAGOON MESOCOSMS}
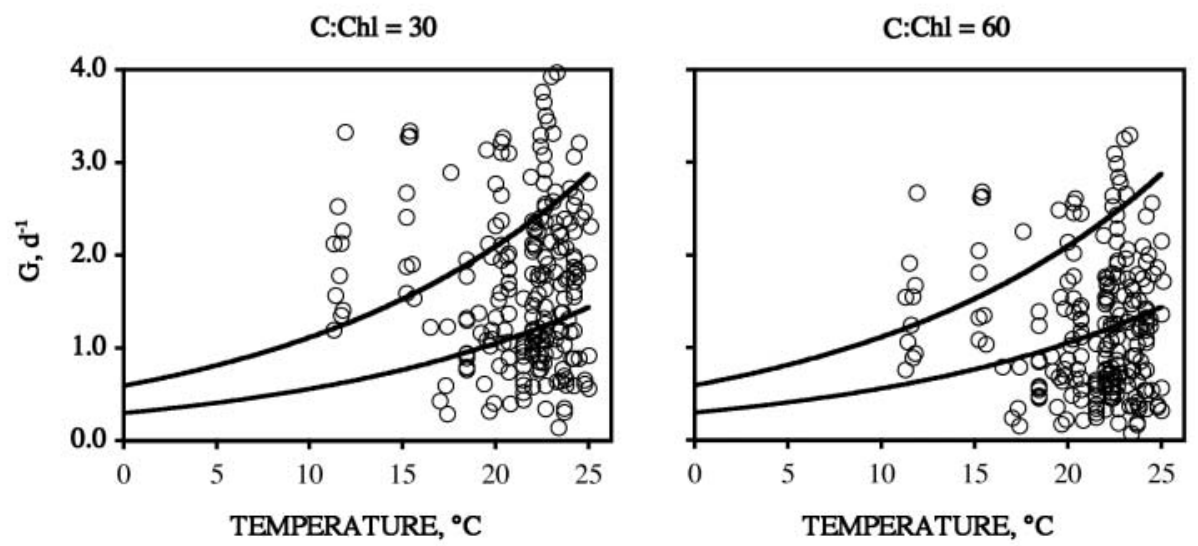

Fig. 5. Instantaneous daily growth rates (base e) calculated from chlorophyll a concentrations and $\mathrm{O}_{2}$-based productivity measured in (a) Waquoit Bay, MA, and (b) the Lagoon Mesocosm Facility, RI. See text for details of the measurements. Upper curve is the Eppley curve. Lower curve is the Eppley curve reduced by $50 \%$ to account for photoperiod and limitation by light and nutrients. Measured rates represent net community production and are more comparable to the lower curve

to $\left.G_{\max }\right)$, which introduces the same problems discussed so far. While Geider (1993) suggests that $P_{\max }$ is determined largely by conditioning to growth irradiance, models of temperate estuaries and lakes would certainly have to force $P_{\max }$ as a function of temperature due to the large annual range in temperature in these systems. Behrenfeld \& Falkowski (1997, their Fig. 4) present several temperature functions which have been used to set $P_{\max }\left(P_{\mathrm{opt}}\right.$ in their terminology) in these detailed $P-I$ models, one of which is the Eppley curve, and there is such a large difference between these functions that it would be most difficult to choose among them. Considering the difficulty in specifying $P_{\max }$ it is worth noting that Behrenfeld \& Falkowski (1997) list the selection of this parameter as second in importance only to depth-integrated biomass in contributing to variability in predicted production.

Still another approach would be to replace the traditional formulations for growth rate (i.e. Eqs. 1 \& 3) with one of the increasingly sophisticated bio-optical models of primary production which are based on para- meters that describe phytoplankton photophysiology (e.g. Sosik 1996). Production in these models is computed as a function of irradiance, maximum photosynthetic quantum yield, photosystem II functional absorption cross-section, turnover time for carbon fixation, and pigment-specific light absorption. However, this approach requires the specification of a variety of parameters which can themselves vary with temperature, irradiance, and nutrient availability (Sosik 1996). As with the $P-I$ models, such variations call into question the usefulness of this approach for overcoming the problem with the Eppley curve.

\section{An empirical alternative}

The first 2 solutions discussed above continue to rely on the Eppley curve, and therefore on a relationship developed in culture, to predict production in the field. All 4 of the approaches discussed thus far involve substantial uncertainties. We have therefore chosen to 


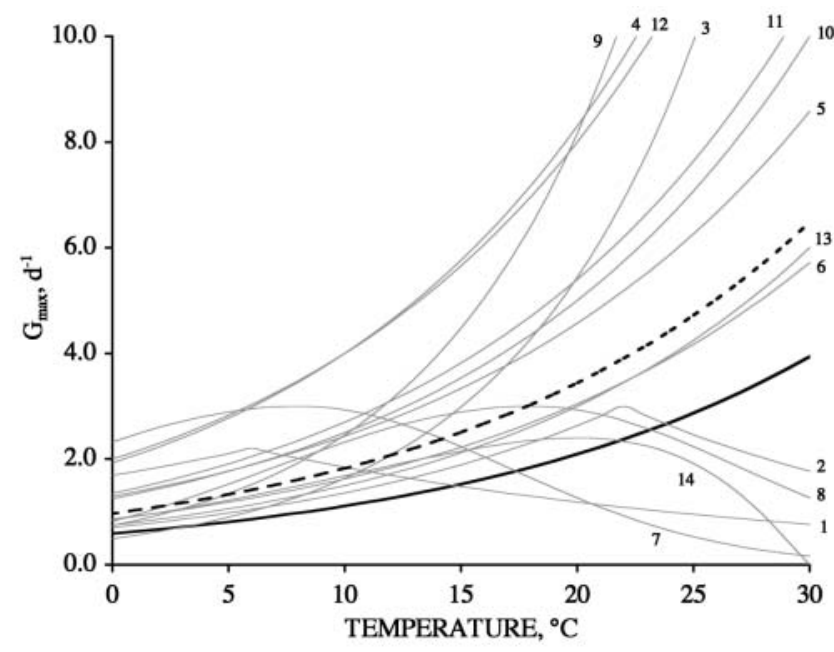

Fig. 6. Temperature-dependent functions for the maximum daily phytoplankton growth rate (base e) in a variety of dynamic simulation models in which this function exceeds the Eppley curve (bold line) over part or all of the seasonal temperature range. The proposed new upper envelope of the culture data in Fig. 3 (Eq. 5) is plotted for comparison (dashed line). Sources which use elevated temperature functions include models of the following systems and species groups: 1, Long Island Sound winter diatoms (HydroQual 1991); 2, Long Island Sound summer assemblage (HydroQual 1991); 3, Baltic Sea (Savchuck \& Wulff 1993); 4, Westerschelde estuary, Netherlands (Soetaert et al. 1994); 5, North Sea diatoms (Aksnes et al. 1995, Skogen et al. 1995); 6, North Sea flagellates (Aksnes et al. 1995, Skogen et al. 1995); 7, Massachusetts and Cape Cod Bays winter diatoms (HydroQual \& Normandeau Associates 1995); 8, Massachusetts and Cape Cod Bays summer assemblage (HydroQual \& Normandeau Associates 1995); 9, Baltic Sea (Savchuck \& Wulff 1996); 10, North Sea diatoms (Baretta-Bekker et al. 1997); 11, North Sea autotrophic flagellates (Baretta-Bekker et al. 1997); 12, North Sea picoalgae (Baretta-Bekker et al. 1997); 13, North Sea dinoflagellates (Baretta-Bekker et al. 1997); 14, Lagoon of Venice and Adriatic Sea (Bergamasco et al. 1998)

investigate a fifth solution which is simple, is widely applicable, does not involve parameter estimation, and is based on actual measurements of phytoplankton production. Cole \& Cloern (1987) demonstrated a strong $\left(\mathrm{r}^{2}=0.82\right)$ linear relationship between daily photic zone productivity $\left(P_{\mathrm{d}}, \mathrm{mg} \mathrm{C} \mathrm{m} \mathrm{m}^{-2} \mathrm{~d}^{-1}\right)$ measured using ${ }^{14} \mathrm{C}$ and the composite parameter $B Z_{\mathrm{p}} I_{0}$, where $B=$ phytoplankton biomass measured as chl a (mg $\mathrm{m}^{-3}$ ), $Z_{\mathrm{p}}=$ depth of the photic zone $(\mathrm{m})$ (defined as the depth of the $1 \%$ light level), and $I_{0}=$ surface irradiance (photosynthetically active radiation, PAR) $\left(\mathrm{E} \mathrm{m}^{-2} \mathrm{~d}^{-1}\right)$. The empirical regression for their pooled dataset from North and South San Francisco Bay, Puget Sound, and the New York Bight was:

$$
P_{\mathrm{d}}=150+0.73\left(B Z_{\mathrm{p}} I_{0}\right)
$$

Similar linear relationships were demonstrated for Delaware Bay and the Neuse River, but data from these systems were not included in the pooled dataset. An alternate expression of this relationship was developed by Cole \& Cloern (1984) previously for San Francisco Bay:

$$
P_{\mathrm{d}}=58+3.8\left(B I_{0} / \mathrm{k}\right)
$$

where $k$ is the vertical attenuation coefficient for light $\left(\mathrm{m}^{-1}\right)$. The 2 expressions are related by $Z_{\mathrm{p}}=4.61 / \mathrm{k}$.

Since Cole \& Cloern published their regressions, similar empirical relationships have been demonstrated in Delaware Bay (Harding et al. 1986, Pennock \& Sharp 1986), Chesapeake Bay (Harding et al. 1986), Narragansett Bay and MERL (Keller 1988a,b), Tomales Bay (Cole 1989), the Neuse River (Mallin et al. 1991, Boyer et al. 1993), the Westerschelde estuary (The Netherlands; Kromkamp et al. 1995), and Boston Harbor and Massachusetts Bay (Kelly \& Doering 1997). The various regressions are summarized in Table 2.

The $B Z_{\mathrm{p}} I_{0}$ empirical regressions describe ${ }^{14} \mathrm{C}$-based, depth-integrated daily production as a function of biomass and a term which quantifies light availability in the water column $\left(Z_{\mathrm{p}} I_{0}\right.$ or $\left.I_{0} / k\right)$. The application of such a relationship to compute production dates back to Ryther \& Yentsch (1957). The $B Z_{\mathrm{p}} I_{0}$ regressions in Table 2 have been demonstrated in nutrient-rich estuaries, in which productivity is expected to be primarily limited by light. As such, the regressions can be considered extensions of the linear relationship between surface irradiance and production normalized to biomass in the light-limited region of the productionirradiance curve (Falkowski 1981, Platt 1986), in which light controls production rather than the nutrient supply. The latter relationship has been found to apply over wide variations in chlorophyll, nutrients, temperature, species composition, and vertical distributions of the phytoplankton (Falkowski 1981), so it is not surprising that the $B Z_{\mathrm{p}} I_{0}$ relationship has a similar wide applicability.

The $B Z_{\mathrm{p}} I_{0}$ regressions consistently explain the majority of the variation in production data, and with few exceptions the slopes are remarkably consistent among regressions (Table 2). Noticeably lower slopes have been reported for Delaware Bay and the Westerschelde estuary, which could be due to the fact that both are highly turbid systems. Cole et al. (1986) found no significant differences between the slopes of the $B Z_{\mathrm{p}} I_{0}$ regressions when computed for 3 size fractions of plankton and for the pooled data set (Table 2). Such strength and consistency in the $B Z_{\mathrm{p}} I_{0}$ relationship across several coastal systems indicates that it could be a useful alternative to the Eppley curve for predicting primary production in simulation models. The $y$-intercepts suggest there is net production in the absence of chlorophyll and/or light (when $B Z_{\mathrm{p}} I_{0}=0$ ), so these regressions should actually be forced through the 
Table 2. Empirical models of daily photic zone production as a function of phytoplankton biomass and light availability. Intercepts and coefficients have been converted where necessary to predict production in units of $\mathrm{mg} \mathrm{C} \mathrm{m}^{-2} \mathrm{~d}^{-1}$. Regressions reported as a function of $B I_{0} / \mathrm{k}$ have been converted to $B Z_{\mathrm{p}} I_{0}$ format using $Z_{\mathrm{p}}=4.61 / \mathrm{k}$

\begin{tabular}{|c|c|c|c|}
\hline Source & Study area & Regression & $\mathrm{r}^{2}$ \\
\hline Cole \& Cloern (1984) & San Francisco Bay & $P_{\mathrm{d}}=58+0.82\left(B Z_{\mathrm{p}} I_{0}\right)$ & 0.82 \\
\hline Cole et al. (1986) & $\begin{array}{l}\text { San Francisco Bay } \\
\text { Unfractionated } \\
\text { Netplankton } \\
\text { Nanoplankton } \\
\text { Ultraplankton }\end{array}$ & $\begin{array}{l}P_{\mathrm{d}}=57+0.81\left(B Z_{\mathrm{p}} I_{0}\right) \\
P_{\mathrm{d}}=34+0.73\left(B Z_{\mathrm{p}} I_{0}\right) \\
P_{\mathrm{d}}=28+0.73\left(B Z_{\mathrm{p}} I_{0}\right) \\
P_{\mathrm{d}}=25+0.76\left(B Z_{\mathrm{p}} I_{0}\right)\end{array}$ & $\begin{array}{l}0.81 \\
0.73 \\
0.75 \\
0.55\end{array}$ \\
\hline Harding et al. $(1986)^{\mathrm{a}}$ & $\begin{array}{l}\text { Chesapeake Bay } \\
\text { Delaware Bay }\end{array}$ & $\begin{array}{l}P_{\mathrm{d}}=176+0.74\left(B Z_{\mathrm{p}} I_{0}\right) \\
P_{\mathrm{d}}=131+0.39\left(B Z_{\mathrm{p}} I_{0}\right)\end{array}$ & $\begin{array}{l}0.69 \\
0.76\end{array}$ \\
\hline Pennock \& Sharp $(1986)^{b}$ & $\begin{array}{l}\text { Delaware Bay } \\
\text { Non-summer } \\
\text { Summer }\end{array}$ & $\begin{array}{l}P_{\mathrm{d}}=100+0.07\left(B Z_{\mathrm{p}} I_{0}\right) \\
P_{\mathrm{d}}=300+0.23\left(B Z_{\mathrm{p}} I_{0}\right)\end{array}$ & $\begin{array}{l}0.68 \\
0.42\end{array}$ \\
\hline Cole \& Cloern (1987) & San Francisco Bay, Puget Sound, New York Bight & $P_{\mathrm{d}}=150+0.73\left(B Z_{\mathrm{p}} I_{0}\right)$ & 0.82 \\
\hline Cloern (1987) & $\begin{array}{l}\text { South San Francisco Bay } \\
\text { North San Francisco Bay }\end{array}$ & $\begin{array}{l}P_{\mathrm{d}}=94+0.88\left(B Z_{\mathrm{p}} I_{0}\right) \\
P_{\mathrm{d}}=63+0.67\left(B Z_{\mathrm{p}} I_{0}\right)\end{array}$ & $\begin{array}{l}0.88 \\
0.72\end{array}$ \\
\hline Keller (1988a) & MERL & $P_{\mathrm{d}}=199+0.59\left(B Z_{\mathrm{p}} I_{0}\right)$ & 0.86 \\
\hline Keller (1988b) & Narragansett Bay, MERL & $P_{\mathrm{d}}=220+0.70\left(B Z_{\mathrm{p}} I_{0}\right)$ & 0.82 \\
\hline Cole (1989) & Tomales Bay & $P_{\mathrm{d}}=125+0.75\left(B Z_{\mathrm{p}} I_{0}\right)$ & 0.90 \\
\hline Cloern (1991) & San Francisco Bay & $P_{\mathrm{d}}=1.1\left(B Z_{\mathrm{p}} I_{0}\right)$ & 0.93 \\
\hline Mallin et al. (1991) & Neuse River estuary & Not reported & 0.73 \\
\hline Boyer et al. (1993) & Neuse River estuary & $\ln P_{\mathrm{d}}=-80+960 \ln \left(B Z_{\mathrm{p}} I_{0}\right)$ & 0.66 \\
\hline Kromkamp et al. (1995) & Westerschelde estuary & See footnote ${ }^{c}$ & \\
\hline Kelly \& Doering (1997) & Massachusetts Bay, Boston Harbor & $P_{\mathrm{d}}=285+0.79\left(B Z_{\mathrm{p}} I_{0}\right)$ & 0.66 \\
\hline \multicolumn{4}{|c|}{$\begin{array}{l}{ }^{\text {a }} \text { The authors report their relationship as a function of } B I_{0} k_{\mathrm{c}} / k_{t} \text {, distinguishing between the attenuation coefficient due to the } \\
\text { chlorophyll }\left(k_{\mathrm{c}}\right) \text { and the total attenuation coefficient }\left(k_{t}\right) \text {. The expression was converted to } B Z_{\mathrm{p}} I_{0} \text { format using Harding et al.'s } \\
\text { definition of } k_{\mathrm{c}}\left[=0.015 \mathrm{~m}^{-1}\left(\mathrm{mg} \mathrm{chl} \mathrm{a} \mathrm{m}^{-3}\right)^{-1} \text { ] and the data in their Table } 5\right. \\
{ }^{\mathrm{b}} \text { Regression slopes and intercepts estimated from Fig. } 7 \text { in Pennock \& Sharp (1986) }\end{array}$} \\
\hline
\end{tabular}

origin, as was done by Cloern (1991) in an analysis of data from San Francisco Bay (Table 2).

While use of such a formulation would deviate from the traditional use of mechanistic formulations based on first principles in such models, the use of a robust, widely applicable function actually rooted in measured ${ }^{14} \mathrm{C}$ production data is justified in light of the fact that the existing mechanistic approach frequently underestimates production. We propose to use predicted chlorophyll, $k$, and forced $I_{0}$ during each time step of our models to compute daily productivity with a $B Z_{\mathrm{p}} I_{0}$ regression. The predicted rate can then be converted to a growth rate using the biomass and C:chl ratio, or used to grow phytoplankton biomass directly, depending on the integration scheme.

\section{Comparison of Eppley and $B Z_{\mathrm{p}} I_{0}$ predictions}

A simple model was developed to compare rates of production calculated using the traditional approach based on the Eppley curve and the alternative $B Z_{\mathrm{p}} I_{0}$ approach. Average annual cycles of temperature and photoperiod were taken from Kremer \& Nixon's (1978) model of Narragansett Bay:

$$
T\left({ }^{\circ} \mathrm{C}\right)=11.5-8.5 \cos [2 \pi(\text { day }-40) / 365]
$$

$f($ dimensionless $)=0.5-0.125 \cos [2 \pi($ day +10$) / 365]$

The average annual cycle of PAR for Narragansett Bay was developed using daily data collected by MERL and the Eppley Laboratory in Newport, RI:

$$
I_{0}\left(\mathrm{E} \mathrm{m}^{-2} \mathrm{~d}^{-1}\right)=30-19 \cos [2 \pi(\text { day }) / 365]
$$

We modeled 3 scenarios in which chlorophyll and the vertical attenuation coefficient for light were held at constant values for a full year:

- Model 1: Chl $a=1 \mathrm{mg} \mathrm{m}^{-3}, k=0.2 \mathrm{~m}^{-1}$

- Model 2: Chl $a=10 \mathrm{mg} \mathrm{m}^{-3}, k=0.4 \mathrm{~m}^{-1}$

- Model 3: Chl $a=50 \mathrm{mg} \mathrm{m}^{-3}, k=1.2 \mathrm{~m}^{-1}$

Depth $(z)$ was set at the photic depth $(=4.61 / k)$ in each model. The scenarios span the typical range in 
chlorophyll and attenuation in temperate estuaries, from relatively clear, oligotrophic waters (Model 1) to turbid, eutrophic waters (Model 3).

Daily production in the Eppley-based model was computed by multiplying the maximum daily growth rate by a term to account for photoperiod and light limitation (after Kremer \& Nixon 1978):

$$
\begin{aligned}
& G=0.59 \mathrm{e}^{(0.0633 T)} \\
& 0.85 \frac{e f}{k z}\left\{\exp \left[\left(-\frac{I_{0}}{I_{\text {opt }}}\right) \mathrm{e}^{-k z}\right]-\exp \left(-\frac{I_{0}}{I_{\text {opt }}}\right)\right\}
\end{aligned}
$$

where $I_{\text {opt }}=$ optimal irradiance for photosynthesis $\left(\mathrm{PAR}_{i} \mathrm{E} \mathrm{m}^{-2} \mathrm{~d}^{-1}\right)$. The value of $I_{\text {opt }}$ was computed each day as the weighted moving average of the irradiance at $1 \mathrm{~m}$ after Kremer \& Nixon (1978):

$$
I_{\text {opt }}=0.7 I^{\prime}{ }_{1}+0.2 I^{\prime}{ }_{2}+0.1 I^{\prime}{ }_{3}
$$

where $I_{j}^{\prime}$ is the irradiance at $1 \mathrm{~m} j$ days earlier. The value of $I_{\text {opt }}$ was not permitted to go below a level which results in an average water column irradiance of $3.6 \mathrm{E} \mathrm{m}^{-2} \mathrm{~d}^{-1}$ (PAR). This value is equal to the apparent threshold for bloom formation observed by Riley (1967), and the approach is that of Kremer \& Nixon (1978).

Daily production was computed each day for $1 \mathrm{yr}$ using the following equation at $\mathrm{C}: \mathrm{chl}=30$ and 60 :

$$
P_{\mathrm{d}}\left(\mathrm{gC} \mathrm{m}^{-2} \mathrm{~d}^{-1}\right)=\left(\mathrm{chl} \cdot \frac{\mathrm{C}}{\mathrm{chl}} \cdot \mathrm{e}^{\mathrm{G}}\right)-\left(\operatorname{chl} \cdot \frac{\mathrm{C}}{\mathrm{chl}}\right)
$$

the year to obtain annual production.

Daily production was also calculated using the $B Z_{\mathrm{p}} I_{0}$ models of Cole \& Cloern (1987), Keller (1988b), and Kelly \& Doering (1997) (Table 2). The $y$-intercepts were set to zero as they are an artifact of linear regression analysis (see above). Daily production was calculated every day for $1 \mathrm{yr}$, and daily values were integrated over the annual cycle.

The $3 \quad B Z_{\mathrm{p}} I_{0}$ equations produce very similar predictions of both daily and annual production (Fig. 7, Table 3). It is remarkable that these relationships, developed in a wide variety of estuarine systems, converge to produce such similar predictions. The sea-

Table 3. Annual production $\left(\mathrm{gC} \mathrm{m}^{-2} \mathrm{yr}^{-1}\right)$ predicted by a simple Eppley curve model and $3 B Z_{\mathrm{p}} I_{0}$ equations. See text for details of each model

\begin{tabular}{|lccc|}
\hline Formulation & Model 1 & Model 2 & Model 3 \\
\hline Eppley curve, C:chl = 30 & 69 & 399 & 835 \\
C:chl = 60 & 137 & 799 & 1669 \\
Cole \& Cloern (1987) & 184 & 970 & 1561 \\
Keller (1988b) & 177 & 930 & 1497 \\
Kelly \& Doering (1997) & 199 & 1049 & 1690 \\
\hline
\end{tabular}
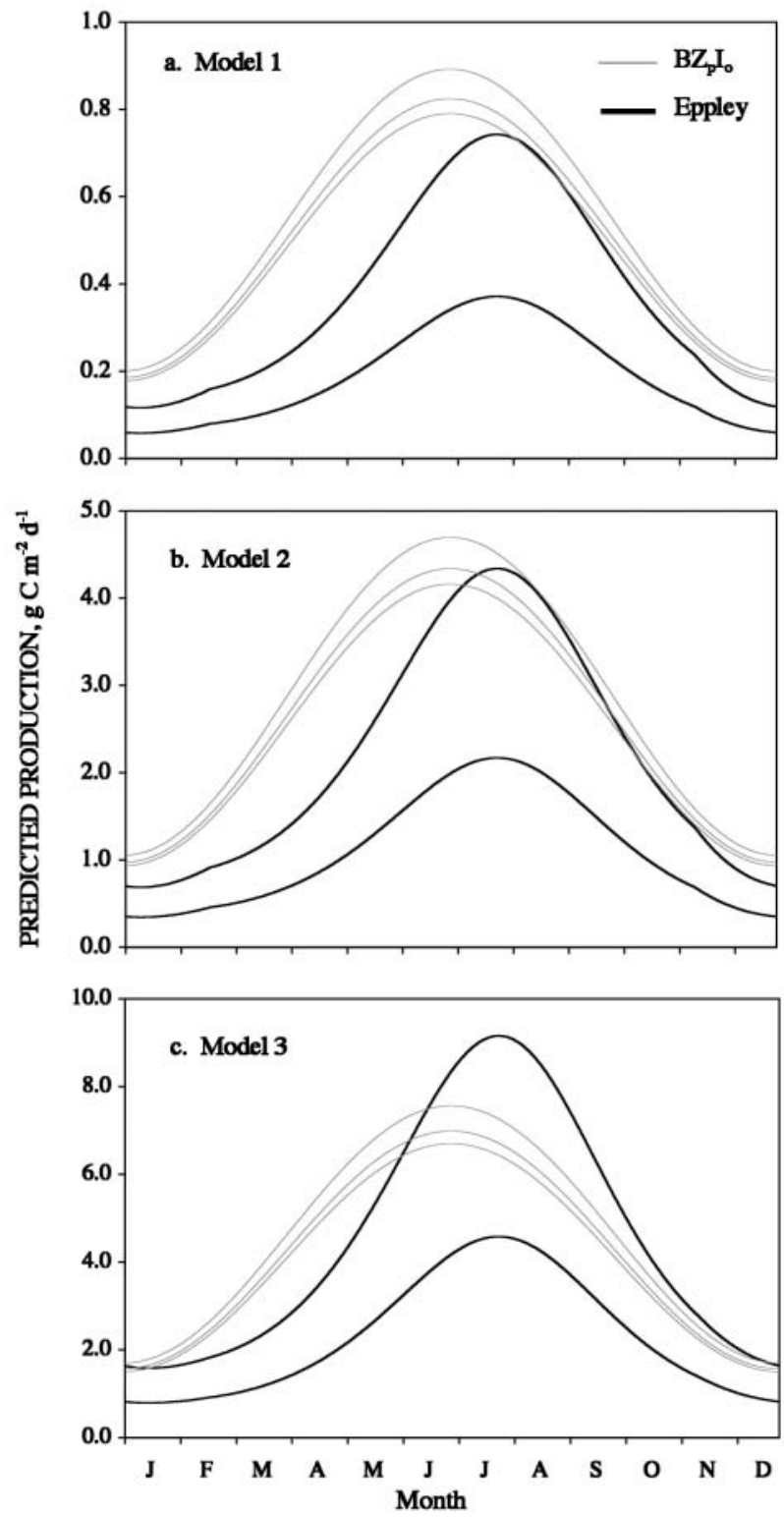

Fig. 7. Daily production calculated for 3 scenarios using a simple model based on the Eppley curve as well as $3 B Z_{\mathrm{p}} I_{0}$ equations. See text for details. Lower Eppley line is for C: $\mathrm{Chl}=30$; upper line is for C:chl $=60$. Upper, middle, and lower $B Z_{\mathrm{p}} I_{0}$ lines were predicted by the relationships of Kelly \& Doering (1997), Cole \& Cloern (1987), and Keller (1988b), respectively

sonal cycles of production predicted by the 2 approaches differ, with the empirical models predicting peak production in June, coincident with the annual maximum in irradiance, and the Eppley model predicting peak production in August, coincident with the annual maximum in temperature (Fig. 7).

The empirical models generally predict higher production than the Eppley model at both C:chl ratios during the winter, spring, and fall (Fig. 7). Only in summer 
and sometimes in the fall when temperatures are highest does the Eppley model predict rates as high as or higher than the $B Z_{\mathrm{p}} I_{0}$ models, and then only at the higher C:chl ratio. The annual integrals for the empirical models exceed those for the Eppley model in the first 2 scenarios (Table 3). For the third scenario, the Eppley prediction at a $\mathrm{C}: \mathrm{chl}$ of 60 is within the range of the $B Z_{\mathrm{p}} I_{0}$ predictions. In all cases, however, the actual $C$ :chl ratio will be somewhere between 30 and 60 on average, so even in the third scenario the $B Z_{\mathrm{p}} I_{0}$ models predict higher rates of production than the Eppley model on an annual basis.

Based on the results of this simple model and the data presented in Figs. 4 \& 5, one might reach the general conclusion that the magnitude of the underestimation that comes from using the Eppley formulation is highly dependent on the C:chl ratio used in the model. Indeed, discrepancies between measured data and the Eppley curve are reduced at the higher C:chl ratio of 60, and the simple model in Fig. 7 and Table 3 also shows some convergence between Eppley and $B Z_{\mathrm{p}} I_{0}$ predictions at higher $\mathrm{C}$ :chl ratios. We caution against the conclusion that the problem with underestimation of production can be taken care of simply by using a higher C:chl ratio. While the results in Figs. 4, 5 \& 7 and Table 3 begin to converge at a C:chl of 60, Eppley nevertheless predicts lower rates even at this upper value. While higher ratios than 60 can certainly occur, it is unlikely that the average ratio in nutrient-rich systems would be higher than 60 (Fig. 2), where phytoplankton cells should be in a generally healthy condition. Additionally, the model of Cerco \& Cole (1994) presented in Table 1 used a C:chl ratio of 75 and still underestimated production. It seems that simply changing the $\mathrm{C}$ :chl ratio is not justified by the available data (Fig. 2) and may not take care of the problem.

\section{Application of $B Z_{\mathrm{p}} I_{0}$}

The $B Z_{\mathrm{p}} I_{0}$ regressions show promise for application in simulation models of nutrient-rich estuaries. These relationships could be directly incorporated into the model code to compute daily production from predicted chlorophyll, $k$, and forced $I_{0}$, and the resulting rates converted to growth rates or used directly to grow phytoplankton biomass. While use of an empirical function deviates from the traditional use of mechanistic formulations based on first principles, we argue that in the face of problems caused by such mechanistic relationships, a sound alternative is to use functions like the $B Z_{\mathrm{p}} I_{0}$ relationships which are rooted in measured data $\left({ }^{14} \mathrm{C}\right)$ and appear to be widely applicable. It is certainly desirable to continue efforts to improve the mechanistic approach, and one hopes that it can be modified so as to eliminate the problem with underestimation of production. Until then, however, it is appropriate to make use of empirical relationships where they exist (Rigler \& Peters 1995).

As discussed above, the $B Z_{\mathrm{p}} I_{0} y$-intercepts are an artifact of curve fitting and should be removed for use in simulation models, as they predict positive production when either biomass or irradiance equal zero. Removal of the $y$-intercept may warrant increasing the slope of the regression slightly, as this would be the result of forcing the regression through zero. Comparing the study of Cloern (1991) in which the $y$-intercept was eliminated to the other studies by Cole and Cloern in San Francisco Bay (which were based on some of the same data) suggests that removal of the $y$-intercept increases the slope of the $B Z_{\mathrm{p}} I_{0}$ regression by a little over $40 \%$ (Table 2 , based on the average slope in all of the other San Francisco Bay regressions).

An additional modification to the slopes may be warranted to account for seasonal differences in the phytoplankton community. While Cole et al. (1986) found little difference among the slopes of the $B Z_{\mathrm{p}} I_{0}$ relationships for 3 size fractions of phytoplankton, Pennock \& Sharp (1986) report a steeper slope for summer as opposed to non-summer populations. Supporting evidence for this seasonal difference is also provided by Keller (1988b), who found steeper slopes between daily production and biomass alone (chlorophyll a) in summer versus non-summer populations.

Despite the absence of a nutrient term in the regressions, it would be necessary to use the available supply of nutrients (standing stock plus inputs in a given time step) to set the maximum limit on daily production. That is, one would use the empirical model to calculate potential production from predicted chlorophyll, attenuation coefficient, and irradiance during each time step, but allow only as much of that production to occur as there are nutrients to support.

One potential problem with applying the $B Z_{\mathrm{p}} I_{0}$ models to shallow systems is that the relationships have been derived in relatively deep estuarine systems in which the photic depth is generally less than the system depth. The models predict production in a water column in which the phytoplankton have access to all of the available light. Such a model would overpredict production in a system in which the depth is less than the theoretical photic depth (at which the 1\% light level would be reached in the absence of a bottom), because the phytoplankton no longer have access to all of the available light. The authors are developing a correction factor which adapts the $B Z_{\mathrm{p}} I_{0}$ model to shallow systems where light reaches the bottom by taking into account the non-linear relationships between depth and irradiance and between irradiance and production. 


\section{CONCLUSIONS}

Existing estuarine simulation models often accurately predict the standing stock of phytoplankton but underestimate the rate of primary production. Many of these models calculate production using the exponential relationship between temperature and growth rate demonstrated by Eppley (1972) for culture data. However, growth rates measured in a variety of culture and field studies exceed those predicted by the Eppley curve. This discrepancy may explain why existing simulation models often underestimate production. The empirical formulation relating daily production to the composite parameter $B Z_{\mathrm{p}} I_{0}$ has been found to apply in a variety of nutrient-rich estuarine systems, and predicts rates of production in excess of those predicted by the Eppley curve. The wide applicability of this relationship, the similarity of the various regressions among systems, and the foundation of the relationship in measured data support the application of the $B Z_{\mathrm{p}} I_{0}$ formulation as an alternative to the Eppley curve in dynamic simulation models of estuarine systems. The authors are currently developing 2 estuarine models which incorporate the $B Z_{\mathrm{p}} I_{0}$ relationship and which will allow a comparison between predictions generated by the empirical formulation and those generated by the traditional approach.

Acknowledgements. The authors wish to sincerely thank C. Oviatt, A. Keller, J. Cloern, S. Granger, J. Bintz, S. Sherwood, I. Valiela, G. Tomasky, J. McClelland, M. Geist, and K. Foreman for graciously compiling and providing the data used in this paper. We are grateful to A. Keller, C. Oviatt, and J. Cloern for their valuable comments and criticism of this work. Funding for this research was provided by Rhode Island Sea Grant (NOAA), Narragansett Electric, and the United States Environmental Protection Agency (grant no. R825757-01-0 to J.N.K.).

\section{LITERATURE CITED}

Aksnes DL, Ulvestad KB, Baliño BM, Berntsen J, Egge JK, Svendsen E (1995) Ecological modelling in coastal waters: towards predictive physical-chemical-biological simulation models. Ophelia 41:5-36

Ambrose RB Jr, Wool TA, Martin JL (1993) The Water Quality Analysis Simulation Program, WASP5. Part A: model documentation. US EPA Environmental Research Laboratory, Athens, GA

Baretta JW, Ebenhöh W, Ruardij P (1995) The European Regional Seas Ecosystem Model, a complex marine ecosystem model. Neth J Sea Res 33(3/4):233-246

Baretta-Bekker JG, Baretta JW, Ebenhöh W (1997) Microbial dynamics in the marine ecosystem model ERSEM II with decoupled carbon assimilation and nutrient uptake. J Sea Res 38:195-211

Behrenfeld MJ, Falkowski PG (1997) A consumer's guide to phytoplankton primary productivity models. Limnol Oceanogr 42(7):1479-1491
Bergamasco A, Carniel S, Pastres R, Pecenik G (1998) A unified approach to the modelling of the Venice LagoonAdriatic Sea ecosystem. Estuar Coast Shelf Sci 46:483-492

Bowie GL, Mills WB, Porcella DB, Campbell CL, Pagenkopf JR, Rupp GL, Johnson KM, Chan PWH, Gherini SA (1985) Rates, constants, and kinetics formulations in surface water quality modeling, 2nd edn. US EPA Environmental Research Laboratory, Athens, GA

Boyer JN, Christian RR, Stanley DW (1993) Patterns of phytoplankton primary productivity in the Neuse River estuary, North Carolina, USA. Mar Ecol Prog Ser 97:287-297

Braarud T (1945) Experimental studies on marine plankton diatoms. Abh Norske Vidensk Acad 10:3-16

Brand LE, Guillard RRL (1981) The effects of continuous light and light intensity on the reproduction rates of twenty-two species of marine phytoplankton. J Exp Mar Biol Ecol 50: $119-132$

Brand LE, Murphy LS, Guillard RRL, Lee HT (1981) Genetic variability and differentiation in the temperature niche component of the diatom Thalassiosira pseudonana. Mar Biol 62(2/3):103-110

Broekhuizen N, Heath MR, Hay SJ, Gurney WSC (1995) Modelling the dynamics of the North Sea's mesozooplankton. Neth J Sea Res 33(3/4):381-406

Castenholz RW (1964) The effect of daylength and light intensity on the growth of littoral marine diatoms in culture. Physiol Plant 17:951-963

Cerco CF, Cole TM (1994) Three-dimensional eutrophication model of Chesapeake Bay. Vol. I: Main report. Technical report EL-94-4, US Army Corps of Engineers Waterways Experiment Station, Vicksburg, MS

Cerco CF, Bunch B, Cialone MA, Wang H (1994) Hydrodynamics and eutrophication model study of Indian River and Rehoboth Bay, Delaware. Technical report EL-94-5, US Army Corps of Engineers Waterways Experiment Station, Vicksburg, MS

Cloern JE (1987) Turbidity as a control on phytoplankton biomass and productivity in estuaries. Cont Shelf Res 7(11/12):1367-1381

Cloern JE (1991) Annual variations in river flow and primary production in the South San Francisco Bay Estuary (USA). In: Elliott M, Ducrotoy D (eds) Estuaries and coasts: spatial and temporal intercomparisons. Olsen and Olsen, Fredensborg, p 91-96

Cloern JE, Grenz C, Vidergar-Lucas L (1995) An empirical model of the phytoplankton chlorophyll:carbon ratio- the conversion factor between productivity and growth rate. Limnol Oceanogr 40(7):1313-1321

Cole BE (1989) Temporal and spatial patterns of phytoplankton production in Tomales Bay, California, U.S.A. Estuar Coast Shelf Sci 28:103-115

Cole BE, Cloern JE (1984) Significance of biomass and light availability to phytoplankton productivity in San Francisco Bay. Mar Ecol Prog Ser 17:15-24

Cole BE, Cloern JE (1987) An empirical model for estimating phytoplankton productivity in estuaries. Mar Ecol Prog Ser 36:299-305

Cole BE, Cloern JE, Alpine AE (1986) Biomass and productivity of three phytoplankton size classes in San Francisco Bay. Estuaries 9(2):117-126

Cullen JJ, Geider RJ, Ishizaka J, Kiefer DA, Marra J, Sakshaug E, Raven JA (1993) Towards a general description of phytoplankton growth for biogeochemical models. In: Evans GT, Fasham MJR (eds) Towards a model of ocean biogeochemical processes. NATO ASI Series I 10, Springer-Verlag, Berlin, p 153-176

Curl H Jr, McLeod GC (1961) The physiological ecology of 
a marine diatom, Skeletonema costatum (Grev.) Cleve. J Mar Res 19(2):70-88

Davis CO, Harrison PJ, Dugdale RC (1973) Continuous culture of marine diatoms under silicate limitation. I. Synchronized life cycle of Skeletonema costatum. J Phycol 9: 175-180

DiToro DM, Connolly JP (1980) Mathematical models of water quality in large lakes. Part 2: Lake Erie. US EPA Environmental Research Laboratory, Duluth, MN

DiToro DM, Matystik WF Jr (1980) Mathematical models of water quality in large lakes. Part 1: Lake Huron and Saginaw Bay. US EPA Environmental Research Laboratory, Duluth, MN

DiToro DM, O'Connor DJ, Thomann RV (1971) A dynamic model of the phytoplankton population in the SacramentoSan Joaquin Delta. In: Hem JD (ed) Nonequilibrium systems in natural water chemistry. Advances in Chemistry Series 106, American Chemical Society, Washington, DC, p 131-180

DiToro DM, Thomann RV, O'Connor DJ, Mancini JL (1977) Estuarine phytoplankton biomass models-verification analyses and preliminary applications. In: Goldberg ED, McCave IN, O'Brien JJ, Steele JH (eds) The sea: ideas and observations on progress in the study of the seas, Vol 6, Marine modeling. Wiley \& Sons, New York, p 969-1020

Durbin EG (1974) Studies on the autecology of the marine diatom Thalassiosira nordenskiöldii Cleve. 1. The influence of daylength, light intensity, and temperature on growth. J Phycol 10:220-225

Ebenhöh W, Kohlmeier C, Radford PJ (1995) The benthic biological submodel in the European Regional Seas Ecosystem Model. Neth J Sea Res 33(3/4):423-452

Elmgren R (1984) Trophic dynamics in the enclosed, brackish Baltic Sea. Rapp P-V Rèun Cons Int Explor Mer 183: 152-169

Elmgren R (1989) Man's impact on the ecosystem of the Baltic Sea: energy flows today and at the turn of the century. Ambio 18(6):326-332

Eppley RW (1972) Temperature and phytoplankton growth in the sea. Fish Bull 70(4):1063-1085

Evans GT, Parslow JS (1985) A model of annual plankton cycles. Biol Oceanogr 3(3):327-347

Falkowski PG (1981) Light-shade adaptation and assimilation numbers. J Plankton Res 3(2):203-216

Fasham MJR, Ducklow HW, McKelvie SM (1990) A nitrogenbased model of plankton dynamics in the oceanic mixed layer. J Mar Res 48:591-639

Fransz HG, Mommaerts JP, Radach G (1991) Ecological modelling of the North Sea. Neth J Sea Res 28(1/2):67-140

Furnas M (1978) Influence of temperature and cell size on the division rate and chemical content of the diatom Chaetoceros curvisetum Cleve. J Exp Mar Biol Ecol 34:97-109

Gallagher JC (1982) Physiological variation and electrophoretic banding patterns of genetically different seasonal populations of Skeletonema costatum (Bacillariophyceae). J Phycol 18:148-162

Geider RJ (1993) Quantitative phytoplankton physiology: implications for primary production and phytoplankton growth. ICES Mar Sci Symp 197:52-62

Goldman JC, McCarthy JJ (1978) Steady state growth and ammonium uptake of a fast-growing marine diatom. Limnol Oceanogr 23(4):695-703

Guillard RRL, Ryther JH (1962) Studies of marine planktonic diatoms. I. Cyclotella nana Hustedt, and Detonula confervacea (Cleve) Gran. Can J Microbiol 8:229-239

Harding LW Jr, Meeson BW, Fisher TR Jr (1986) Phytoplankton production in two east coast estuaries: photosynthesis- light functions and patterns of carbon assimilation in Chesapeake and Delaware Bays. Estuar Coast Shelf Sci 23:773-806

Hofmann EE, Ambler JW (1988) Plankton dynamics on the outer southeastern U.S. continental shelf. Part II: a timedependent biological model. J Mar Res 46:883-917

Hofmann EE, Lascara CM (1998) Overview of interdisciplinary modeling for marine ecosystems. In: Brink $\mathrm{KH}$, Robinson AR (eds) The sea, Vol 10: The global coastal ocean: processes and methods. John Wiley \& Sons, New York, p 507-540

HydroQual (1987) A steady-state coupled hydrodynamic/ water quality model of the eutrophication and anoxia process in Chesapeake Bay. Final report to the US EPA Chesapeake Bay Program. HydroQual, Mahwah, NJ

HydroQual (1991) Water quality modeling analysis of hypoxia in Long Island Sound. Report to the Management Committee of the Long Island Sound Estuary Study and the New England Interstate Water Pollution Control Commission. HydroQual, Mahwah, NJ

HydroQual, Normandeau Associates (1995) A water quality model for Massachusetts and Cape Cod Bays: calibration of the Bays Eutrophication Model (BEM). Report to the Massachusetts Water Resources Authority. HydroQual, Mahwah, NJ, and Normandeau Associates, Bedford, NH

Jørgensen SE (1976) A eutrophication model for a lake. Ecol Model 2:147-165

Keller AA (1988a) An empirical model of primary productivity $\left({ }^{14} \mathrm{C}\right)$ using mesocosm data along a nutrient gradient. J Plankton Res 10(4):813-834

Keller AA (1988b) Estimating phytoplankton productivity from light availability and biomass in the MERL mesocosms and Narragansett Bay. Mar Ecol Prog Ser 45:159-168

Kelly JR, Doering PH (1997) Monitoring and modeling primary production in coastal waters: studies in Massachusetts Bay 1992-1994. Mar Ecol Prog Ser 148:155-168

Krawiec RW (1982) Autecology and clonal variability of the marine centric diatom Thalassiosira rotula (Bacillariophyceae) in response to light, temperature and salinity. Mar Biol 69:79-89

Kremer JN, Nixon SW (1978) A coastal marine ecosystem: simulation and analysis. Springer-Verlag, New York

Kromkamp J, Peene J, van Rijswijk P, Sandee A, Goosen N (1995) Nutrients, light and primary production by phytoplankton and microphytobenthos in the eutrophic, turbid Westerschelde estuary (The Netherlands). Hydrobiologia 311:9-19

Langdon C (1987) On the causes of interspecific differences in the growth-irradiance relationship for phytoplankton. Part I. A comparative study of the growth-irradiance relationship of three marine phytoplankton species: Skeletonema costatum, Olisthodiscus luteus and Gonyaulax tamarensis. J Plankton Res 9(3):459-482

Langdon C (1988) On the causes of interspecific differences in the growth-irradiance relationship for phytoplankton. II. A general review. J Plankton Res 10(6):1291-1312

Madden CJ, Kemp WM (1996) Ecosystem model of an estuarine submersed plant community: calibration and simulation of eutrophication responses. Estuaries 19(2B):457-474

Mallin MA, Paerl HW, Rudek J (1991) Seasonal phytoplankton composition, productivity and biomass in the Neuse River estuary, North Carolina. Estuar Coast Shelf Sci 32: 609-623

Matear RJ (1995) Parameter optimization and analysis of ecosystem models using simulated annealing: a case study at Station P. J Mar Res 53:571-607

Milliken AS (1991) Diel metabolism of coastal lagoons in 
response to nitrate enrichment: a mesocosm experiment. MS thesis, University of Rhode Island, Narragansett, RI Nixon SW, Ducklow H, Hofmann E, Smith G, Gross G (1999) Review of the Chesapeake Bay Water Quality Model. Chesapeake Bay Research Consortium, Edgewater, MD

Odum HT, Hoskin CM (1958) Comparative studies on the metabolism of marine waters. Publ Inst Mar Sci Univ Texas 5:16-46

Oviatt CA, Keller AA, Sampou PA, Beatty LL (1986) Patterns of productivity during eutrophication in a mesocosms experiment. Mar Ecol Prog Ser 28:69-80

Oviatt CA, Keller AA, Reed L (2002) Annual primary production in Narragansett Bay with no bay-wide winter-spring phytoplankton bloom. Estuar Coast Shelf Sci 54(6): 1013-1026

Paasche E (1967) Marine plankton algae grown with light-dark cycles. I. Coccolithus huxleyi. Physiol Plant 20:946-956

Paasche E (1968) Marine plankton algae grown with lightdark cycles. II. Ditylum brightwellii and Nitzschia turgidula. Physiol Plant 21:66-77

Paasche E (1973) Silicon and the ecology of marine plankton diatoms. I. Thalassiosira pseudonana (Cyclotella nana) grown in a chemostat with silicate as limiting nutrient. Mar Biol 19:117-126

Parsons TR, Stephens K, Strickland JDH (1961) On the chemical composition of eleven species of marine phytoplankters. J Fish Res Board Can 18(6):1001-1016

Pennock JR, Sharp JH (1986) Phytoplankton production in the Delaware Estuary: temporal and spatial variability. Mar Ecol Prog Ser 34:143-155

Platt T (1986) Primary production of the ocean water column as a function of surface light intensity: algorithms for remote sensing. Deep-Sea Res 33(2):149-163

Platt T, Jassby A (1976) The relationship between photosynthesis and light for natural assemblages of coastal marine phytoplankton. J Phycol 12:421-430

Platt T, Sathyendranath S, Ravindran P (1990) Primary production by phytoplankton: analytic solutions for daily rates per unit area of water surface. Proc R Soc Lond B Biol Sci 241:101-111

Rigler FH, Peters RH (1995) Science and limnology. In: Kinne O (ed) Excellence in ecology, Vol 6. Ecology Institute, Oldendorf/Luhe

Riley GA (1967) The plankton of estuaries. In: Lauff GH (ed) Estuaries. Publ no. 83. American Association for the Advancement of Science, Washington, DC, p 316-326

Ryther JH, Yentsch CS (1957) The estimation of phytoplankton production in the ocean from chlorophyll and light data. Limnol Oceanogr 2:281-286

Sakshaug E, Andresen K (1986) Effect of light regime upon growth rate and chemical composition of a clone of Skeletonema costatum from the Trondheimsfjord, Norway. J Plankton Res 8(4):619-637

Sakshaug E, Holm-Hansen O (1977) Chemical composition of Skeletonema costatum (Grev.) Cleve and Pavlova (Mono-

Editorial responsibility: Kenneth Tenore (Contributing

Editor), Solomons, Maryland, USA chrysis) lutheri (Droop) Green as a function of nitratephosphate-, and iron-limited growth. J Exp Mar Biol Ecol 29:1-34

Savchuk O, Wulff F (1993) Biogeochemical transformations of nitrogen and phosphorus: a pelagic submodel for the Baltic Sea. Systems Ecology Contributions No. 1, Stockholm University

Savchuk O, Wulff F (1996) Biogeochemical transformations of nitrogen and phosphorus in the marine environment: coupling hydrodynamic and biogeochemical processes in models for the Baltic proper. Systems Ecology Contributions No. 2, Stockholm University

Skogen MD, Svendsen E, Berntsen J, Aksnes D, Ulvestad KB (1995) Modelling the primary production in the North Sea using a coupled three-dimensional physical-chemical-biological ocean model. Estuar Coast Shelf Sci 41:545-565

Smayda TJ (1969) Experimental observations on the influence of temperature, light, and salinity on cell division of the marine diatom, Detonula confervacea (Cleve) Gran. J Phycol 5:150-157

Soetaert K, Herman PMJ, Kromkamp J (1994) Living in the twilight: estimating net phytoplankton growth in the Westerschelde estuary (The Netherlands) by means of an ecosystem model (MOSES). J Plankton Res 16(10): $1277-1301$

Sosik HM (1996) Bio-optical modeling of primary production: consequences of variability in quantum yield and specific absorption. Mar Ecol Prog Ser 143:225-238

Stigebrandt A, Wulff $F$ (1987) A model for the dynamics of nutrients and oxygen in the Baltic proper. J Mar Res 45: 729-759

Taylor D, Nixon S, Granger S, Buckley B (1995) Nutrient limitation and the eutrophication of coastal lagoons. Mar Ecol Prog Ser 127:235-244

Thomann RV, Fitzpatrick JJ (1982) Calibration and verification of a mathematical model of the eutrophication of the Potomac Estuary. Prepared for the Department of Environmental Services, Government of the District of Columbia. HydroQual, Mahwah, NJ

Thomann RV, DiToro DM, Winfield RP, O'Connor DJ (1975) Mathematical modeling of phytoplankton in Lake Ontario. I. Model development and verification. US EPA National Environmental Research Center, Office of Research and Development, Corvallis, OR

Thomas WH, Dodson AN (1975) On silicic acid limitation of diatoms in near-surface waters of the eastern tropical Pacific Ocean. Deep-Sea Res 22:671-677

Throndsen J (1976) Occurrence and productivity of small marine flagellates. Norw J Bot 23:269-293

Verity PG (1982) Effects of temperature, irradiance, and daylength on the marine diatom Leptocylindrus danicus Cleve. IV. Growth. J Exp Mar Biol Ecol 60:209-222

Yoder JA (1979) Effect of temperature on light-limited growth and chemical composition of Skeletonema costatum (Bacillariophyceae). J Phycol 15:362-370

Submitted: July 26, 2000; Accepted: November 15, 2001

Proofs received from author(s): July 23, 2002 